\title{
Vasodilator effect of ethanolic extracts of Passiflora vitifolia and Passiflora edulis f. edulis seeds
}

\author{
Ángel Arturo Jiménez Rodríguez ${ }^{1,2 *}$, Jonh Jairo Méndez Arteaga ${ }^{1}$, Walter Murillo Arango ${ }^{1}$, Mario Francisco Guerrero Pabón ${ }^{2}$ \\ ${ }^{1}$ Department of Chemistry, Faculty of Science, Universidad del Tolima, Tolima, Colombia. \\ ${ }^{2}$ Department of Pharmacy, Faculty of Science, National University of Colombia, Bogota, Colombia.
}

\begin{tabular}{l}
\hline ARTICLE INFO \\
\hline Received on: $19 / 05 / 2020$ \\
Accepted on: 01/05/2021 \\
Available Online: 03/10/2021
\end{tabular}

\section{Key words:}

Bioactive extract, Passiflora, nitric oxide, angiotensin-II, antihypertensives.

\begin{abstract}
Hypertension (HTA) is one of the primary risk factors in cardiovascular diseases and is considered one of the main causes of morbidity and mortality worldwide. Therapeutic alternatives focused on natural products and phytocompounds obtain more interest in the treatment of this type of disease, and species of Passiflora gender have presented scientific interest due to their chemical composition and the different bioactivities that their compounds have reported. This study aimed to evaluate the antihypertensive potential of extracts obtained from seeds of Passiflora vitifolia and Passiflora edulis f. edulis; for this, extraction was carried out by maceration with $97 \%$ ethanol of the seed flour of the two species; the extracts were characterized by qualitative and quantitative tests and UHPLC. Its cytotoxicity, in vivo antihypertensive potential, vasodilator effect, and possible mechanisms of action in vitro models were evaluated. The extracts did not show apparent toxicity, but showed a preventive effect of HTA, inhibited angiotensin-II (AT-II) contraction, and presented relaxation of contracted aortic rings with phenylephrine and $\mathrm{KCl}$, and this was partially reversed in the presence of L-NAME. The results highlight the potential of these Passifloras as a source of extracts with antihypertensive capacity, having as possible mechanisms of action the synthesis of NO and inhibition or antagonism of AT-II.
\end{abstract}

\section{INTRODUCTION}

Cardiovascular diseases (CVDs) have gained a relevant role worldwide by becoming the leading cause of morbidity and mortality, generating around 17.7 million deaths in 2015, which represents $31 \%$ of all deaths recorded in the world for that year (World Health Organization, 2015). Among CVDs, arterial hypertension (HTA) stands out, which is a chronic disease that generates alterations in the organism (damage to arteries, brain, heart, eyes, kidneys, sexual dysfunction, and others) and causes $49 \%$ of related deaths with CVD. At present, HTA is controlled by the prolonged use of drugs with only one pharmacological target (angiotensin-converting enzyme inhibitors, $\beta$-blockers, diuretics, calcium blockers, ARA II,

\section{*Corresponding Author}

Ángel Arturo Jiménez Rodríguez, Department of Chemistry, Faculty of Science, Universidad del Tolima, Tolima, Colombia and Department of Pharmacy, Faculty of Science, National University of Colombia, Bogota, Colombia.E-mail: aajimenezro@ut.edu.co and others), which generate secondary short and long alterations, causing deterioration in the quality of life of the patients (Brown and Bussell, 2011; Piepoli et al., 2016; Rojas, 2009; Tedla and Bautista, 2016), what makes it essential to search for new alternatives such as the use of phytotherapy, diets, supplements, and functional foods that prevent condition and control symptoms without serious side effects (Mantovani et al., 2017; Shouk et al., 2014).In this regard, plants and fruits such as those belonging to the Passifloraceae family, with numerous species, of which various secondary metabolites have been reported among them, alkaloids (harman, harmine, harmalol, and harmaline), flavonoids (vitexin, isovitexin, orientin, vicenin, and isoorientin), saponins (passiflorin and quadranguloside), cyanogenic compounds (passicoriacin and epipassicoriacin), and terpenes (Alvarez et al., 2019; Alves et al., 2020; Ballesteros-Vivas et al., 2019; Ingale and Kasture, 2014; Viganó et al., 2020; Wosch et al., 2015; 2017) have presented different biological activities such as sedative, antihypertensive, antiparkinsonian, antispasmodic, antioxidant, and antiproliferative (Aguillón et al., 2013; Alves et al., 2020; Ballesteros-Vivas et al., 2019; Contreras et al., 2011; Dhawan et al., 2004; Ingale and Kasture, 2014; Ocampo et al., 2010; Pinzón 
et al., 2007; Rudnicki et al., 2007; Viganó et al., 2020). Colombia is recognized worldwide as the center of diversity of Passiflora and the country with the highest number of records, 172 species (58 endemic); among them, Passiflora vitifolia Kunth (gulupa de monte) and Passiflora edulis f. edulis Sims (gulupa) are studied. They are part of wild and cultivated species, of which their possible bioactivities and chemical composition are not fully known, especially their agroindustrial waste ( $80 \%$ of the fresh fruit).

Therefore, this work focused on characterizing chemically and biologically extracts obtained from $P$. vitifolia and $P$. edulis f. edulis, evaluating its cytotoxicity, relaxing capacity, vasodilator potential in vivo and in vitro, and possible mechanisms of antihypertensive action.

\section{MATERIALS AND METHODS}

\section{Plant material}

Passiflora vitifolia was collected in the Alejandro Von Humboldt Botanical Garden of the University of Tolima (N $4^{\circ}$ $15^{\prime}-\mathrm{N} 4^{\circ} 40^{\prime}$ and $\mathrm{W} 75^{\circ} 00^{\prime}-75^{\circ} 30^{\prime}$ ) municipality of Ibagué (Tolima, Colombia); P. edulis f. edulis was collected in the Buenos Aires farm ( $4^{\circ} 26^{\prime} 27^{\prime \prime} \mathrm{N}$ and $\left.75^{\circ} 25^{\prime} 40^{\prime \prime} \mathrm{W}\right)$ municipality of Cajamarca (Tolima, Colombia); ripe fruits were collected for the extraction of seeds, as well as complete specimens (stem, leaves, tendrils, flower, and fruit) for their taxonomic determination in the Colombian National Herbarium, where they were determined as $P$. edulis Sims (COL. 592023) and P. vitifolia Kunth (COL. 592024).

\section{Preparation of extract}

The seeds were dried in an air circulation oven at $45^{\circ} \mathrm{C} \pm 2{ }^{\circ} \mathrm{C}$ and ground, obtaining a flour that was degreased. Ethanolic extracts were obtained by maceration of the flour and degreased with $97 \%$ ethanol; the mixture was vacuum filtered to obtain the crude extract, which was dried under reduced pressure and stored at $-20^{\circ} \mathrm{C}$ (Jiménez et al., 2013); preliminary phytochemical characterization was carried out using colorimetric tests (Dominguez, 1973; Murillo and Méndez, 2012).

\section{Quantitative analysis}

\section{Determination of total phenolic compounds and tannins}

Total phenolic and tannin contents of extracts were determined according to the method described by Viganó et al. (2020) with some modifications. $50 \mu \mathrm{l}$ of each solution was mixed with $800 \mu \mathrm{l}$ of water and $50 \mu \mathrm{l}$ of $15 \% \mathrm{Na}_{2} \mathrm{CO}_{3}$ and was stirred and allowed to stand for 8 minutes. Then, $100 \mu \mathrm{l}$ of Folin-Ciocalteu reagent was added. After 2 hours, absorbance was measured by a microplate lector (Multiskan ${ }^{\mathrm{TM}} \mathrm{GO}$ Thermo scientific $\left.^{\mathrm{TM}}\right)$ at $725 \mathrm{~nm}$. The results were expressed as gallic acid equivalents (g.GAE/100 g sample). In tannins, previously, the sample was incubated with polyvinylpyrrolidone (PVPP $100 \mathrm{mg} /$ $\mathrm{ml}$ of sample) at $4^{\circ} \mathrm{C} / 4$ hours. The mixture was centrifuged at $3,000 \mathrm{rpm}$ for 10 minutes and the supernatant was determined by the method described above. The results were expressed as tannic acid equivalents (g.TAE/100 g sample) (Da Silva et al., 2019).

\section{DETERMINATION OF FLAVONOIDS}

Flavonoids in the extracts were determined according to the method described by Karapetsas et al. (2019) with some modifications. $1 \mathrm{ml}$ of each solution was mixed with $150 \mu \mathrm{l}$ of $5 \%$ sodium nitrite and incubated for 5 minutes at room temperature. $150 \mu \mathrm{l}$ of $10 \% \mathrm{AlCl}_{3}$ ethanolic solution and $2 \mathrm{ml}$ of $4 \%$ sodium hydroxide were added; the solution was gauged to $5 \mathrm{ml}$ with distilled water and incubated for 15 minutes at room temperature. Absorbance was measured by a microplate spectrophotometer (Multiskan $^{\mathrm{TM}} \mathrm{GO}$; Thermo Scientific ${ }^{\mathrm{TM}}$ ) at $510 \mathrm{~nm}$. Total flavonoid content was calculated as equivalents of $\mathrm{g}$ Quercetin (g.QE/100 g sample).

\section{Extract characterization (HPLC-UV)}

This was carried out using high-performance liquid chromatographic analysis on a Waters Alliance 2,695 separation module system, coupled to a dual-channel (320 and $280 \mathrm{~nm}$ ) absorbance $\mathrm{k}$ detector, and a Waters Atlantis dC18 column $(5 \mu \mathrm{m}$; $2.1 \times 150 \mathrm{~mm}$ ) using a gradient system with the conditions used by Delpino-Rius et al. (2015). The following metabolites in the extracts were quantified: chlorogenic acid, caffeic acid, coumaric acid, epicatechin, catechin, gallic acid, isoquercetin, quercetin, rutin, synaptic acid, vitexin, isovitexin, orientin, and isoorientin; by means of the elaboration of calibration curves with standards for their correct quantification.

\section{Toxicity of extract}

Acute toxicity study

The acute toxicity test of extracts was carried out according to the Organization of Economic Cooperation and Development (OECD) guidelines 423 (Schlede et al., 2005). Albino mice $(n=6)$ were treated orally with the extracts prepared in the vehicle [polyethylene glycol:glycerol:Milli-Q water $(10: 10: 80)]$ control group. The fixed-dose $(2,000 \mathrm{mg} / \mathrm{kg})$ method OECD guidelines 423 specified by CPCSEA were implemented for toxicity studies. After the administration of extracts, animals were observed for toxic effect, if any, for the first 4 hours and once daily for 15 days (Saleem et al., 2017).

Cytotoxic activity of the extracts [methyl thiazole tetrazolium (MTT) assay]

The MTT assay (Mosmann, 1983) was carried out using human polymorphonuclear leukocytes (PMNs) obtained from human peripheral blood, evaluating the extracts at different concentrations $(500,1,000,2,000$, and 4,000 $\mu \mathrm{g} / \mathrm{ml})$ (Cárdenas et al., 2012).

\section{Antihypertensive activity in vivo}

\section{Experimental animals}

The Bioethics Committee of the Faculty of Sciences, National University of Colombia, Bogotá headquarters, endorsed the implementation of the project under Act 16 of September 13, 2016. Wistar rats (males and females) 9-11 weeks old, with weights between 250 and $320 \mathrm{~g}$, were supplied by the Bioterium of the Pharmacy Department (Science Faculty), Universidad Nacional de Colombia, Bogotá headquarters, keeping them under controlled conditions (temperature $22^{\circ} \mathrm{C}$, humidity $70 \%$, and light/ dark 12/12 hours). 
In vivo antihypertensive potential of $P$. vitifolia and $P$. edulis extracts

This was carried out using the methodology proposed by Bareño et al. (2017). The experimental animals were randomly divided into groups $(n=6)$, taking into account the treatments that were going to be used (Table 1). Every 48 hours for 7 weeks, the extracts and enalapril (reference drug) were administered orally and L-NAME (nitric oxide synthase inhibitor) was administered intraperitoneally. The measurement of systolic blood pressure (SBP) was made by the tail-cuff method (Tail-Cuff) in an ultrasound transducer (PANLAB-LE 5002) (Bareño et al., 2017; Vanvliet et al., 2000).

\section{Model of vasodilation in isolated aortic rings}

\section{Preparation of the rings}

By thoracotomy, the thoracic aortic artery was removed after the animal was sacrificed in a $\mathrm{CO}_{2}$ camera. It was cleaned of connective tissue and it was divided into 4-5 $\mathrm{mm}$ rings that were kept in Krebs solution $(\mathrm{NaCl} 118.7 ; \mathrm{KCl} 4.7 ; \mathrm{CaCl} 2$ 2.5; NaHC03 25.0; MgS04.7H20 1.2; glucose 11.0; and ascorbic acid $0.1, \mathrm{nM})$ at $37^{\circ} \mathrm{C}$ with carbogen mixture of $95 \% \mathrm{O}_{2}$ and $5 \% \mathrm{CO}_{2}$. The measurement of the tension was made by fixing the rings to the base in the organ chambers containing $10 \mathrm{ml}$ of Krebs solution maintained at $37^{\circ} \mathrm{C}, \mathrm{pH} 7.4 \pm 0.2$, and carbogen and to the isometric transducer coupled to a signal amplification system and computerized recording (Data Trax 2, WPI) (Torres et al., 2012).

Relaxation induced by extracts of $P$. vitifolia and $P$. edulis $\mathbf{f}$. edulis

Phenylephrine $\left(10^{-6} \mathrm{M}\right)$ or $\mathrm{KCl}(60 \mathrm{mM})$ was added to the organ chamber, compounds with which a stable signal of contraction was reached, to each bath; subsequently, the ethanolic extracts dissolved in Dimethyl sulfoxide (DMSO) $(0.1 \%)$ were administered in cumulative concentrations $(1,10,30,100$, and 300 $\mu \mathrm{g} / \mathrm{ml}$ ). As a control, 0.1\% DMSO was used (Bareño et al., 2017; Cupitra et al., 2020).

Effect of acetylcholine (ACh) and sodium nitroprusside (NPS) in aortic rings of hypertensive rats treated with the extracts

Aortic rings from hypertensive rats treated with the extracts and the reference drug were coupled in the organ chambers and contracted with phenylephrine $\left(10^{-6} \mathrm{M}\right)$ until a maximum contraction was obtained; subsequently, cumulative concentrations of ACh were added $\left(1.0^{*} 10^{-4}, 1.0^{*} 10^{-3}, 5.0^{*} 10^{-3}\right.$, $1.0 * 10^{-2}, 5.0 * 10^{-2}, 8.0 * 10^{-2}, 1.0 * 10^{-1}, 3.0 * 10^{-1}, 5.0 * 10^{-1}, 1.0$, $5.0,10,50$, and $100 \mu \mathrm{M})$ and NPS $\left(5.0^{*} 10^{-5}, 1.0^{*} 10^{-4}, 1.0^{*} 10^{-3}\right.$,

Table 1. Distribution of groups and treatments administered.

\begin{tabular}{ccc}
\hline Group & Treatment $\mathbf{1}$ & Treatment $\mathbf{2}$ \\
\hline $\mathbf{1}$ & Extract $P$. edulis $(150 \mathrm{mg} / \mathrm{kg})$ & L-NAME $(30 \mathrm{mg} / \mathrm{kg})$ \\
$\mathbf{2}$ & Extract $P$. vitifolia $(150 \mathrm{mg} / \mathrm{kg})$ & L-NAME $(30 \mathrm{mg} / \mathrm{kg})$ \\
$\mathbf{3}$ & Vehicle & Vehicle \\
$\mathbf{4}$ & Vehicle & L-NAME $(30 \mathrm{mg} / \mathrm{kg})$ \\
$\mathbf{5}$ & Enalapril $(10 \mathrm{mg} / \mathrm{kg})$ & L-NAME $(30 \mathrm{mg} / \mathrm{kg})$ \\
\hline
\end{tabular}

Vehicle: polyethylene glycol: glycerol: Milli-Q water (10:10:80).
$5.0^{*} 10^{-3}, 1.0^{*} 10^{-2}, 5.0 * 10^{-2}, 1.0^{*} 10^{-1}, 5.0^{*} 10^{-1}, 1.0,5$, and 10 $\mu \mathrm{M})$, observing the relaxing potential of these in the different rings.

\section{Action mechanisms of the extracts of $P$. vitifolia and $P$. edulis f. edulis}

They were evaluated using the organ chambers model in aortic rings incubated for 15 minutes with the following agents: atropine (muscarinic antagonist), indomethacin (cyclooxygenase inhibitor), propranolol (beta antagonist), L-NAME (nitric oxide inhibitor synthase), and methylene blue (guanylate cyclase inhibitor) (Brunton et al., 2006; Lorenzo et al., 2008; Torres et al., 2012). Subsequently, the extracts were supplied under the aforementioned conditions and their effect in the presence and absence of the mentioned agents was compared, by adding angiotensin-II (AT-II) to the bath in cumulative concentrations $\left(1 * 10^{-5}, 5^{*} 10^{-5}, 1^{*} 10^{-4}, 5^{*} 10^{-4}, 1^{*} 10^{-3}, 5^{*} 10^{-3}, 1^{*} 10^{-2}, 5^{*} 10^{-2}\right.$, $1 * 10^{-1}$, and $5^{*} 10^{-1}$ until $\left.1 \mu \mathrm{M}\right)$; a contraction curve was established in the rings; the extract effect was verified by incubation for 15 minutes with them at 30 and $300 \mu \mathrm{g} / \mathrm{ml}$, repeating the contraction curve with AT-II and comparing the contraction results obtained in the presence and absence of those extracts.

\section{Data analysis}

Data were expressed as the mean \pm SEM. Statistical analysis was carried out using analysis of variance (two-way parametric), followed by Tukey's multiple difference test ( $p \leq$ 0.05), using the GraphPad Prism 6 program.

\section{RESULTS AND DISCUSSION}

\section{Toxicity of extract}

Acute toxicity

In the acute toxicity test, there were no deaths or toxic signs after administration. The weight gain did not vary in the treated groups compared to the control group. The necropsy did not reveal any macroscopic alteration of the organs and tissues examined.

The extracts of $P$. vitifolia and $P$. edulis f. edulis are framed in the category of not classified according to the Toxicity Classes of the European Community (Commission of the European Communities, 1992), since no mortality or toxic signs are attributable to its administration. According to this result, we can affirm that the evaluated extracts did not produce significant toxicity at the limit dose in the acute toxicity test.

In vitro cytotoxic activity of the extracts (MTT Assay)

Cell viability was established with respect to the vehicle to which a $100 \%$ survival was assigned. In Figure 1, it is evident that extracts at the evaluated concentrations did not show cell viability less than $80 \%$; therefore, these can be considered safe, complying with the parameters proposed by Rodríguez et al. (2004); on the other hand, during the time of administration of the extracts to the animals, they did not present symptoms of apparent toxicity. It is possible that the type and concentration of metabolites present are related to high levels of cell viability, since, for example, under the conditions of this study, it was not possible to detect saponins, which are reported in other plant 


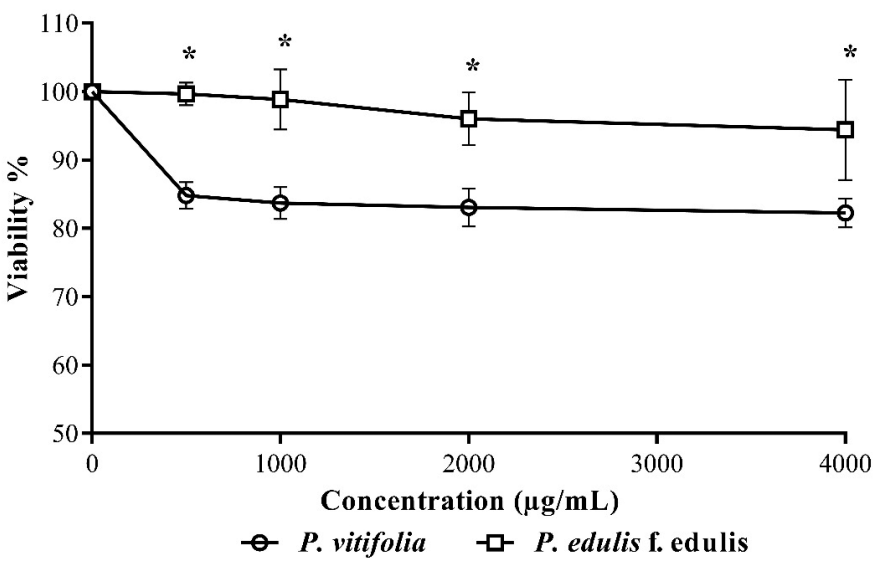

Figure 1. Cytotoxic effect of the extracts against PMNs. Each point represents the mean $\%$ viability $\pm \mathrm{SD}$ of each treatment. * Indicate significant differences $(p \leq 0.05)$

organs (Table 1) and have been reported as toxic in cell models and if the presence of polyphenols is evident (Table 2) which are reported as antioxidants with a cellular protective effect (Orhan et al., 2003; Podolak et al., 2010).

\section{Antihypertensive activity in vivo}

The administered extracts showed an effect against the increase of the SBP of animals after the administration of the L-NAME (Fig. 2); it was evident that the basal values of SBP did not increase with the administration of L-NAME; this

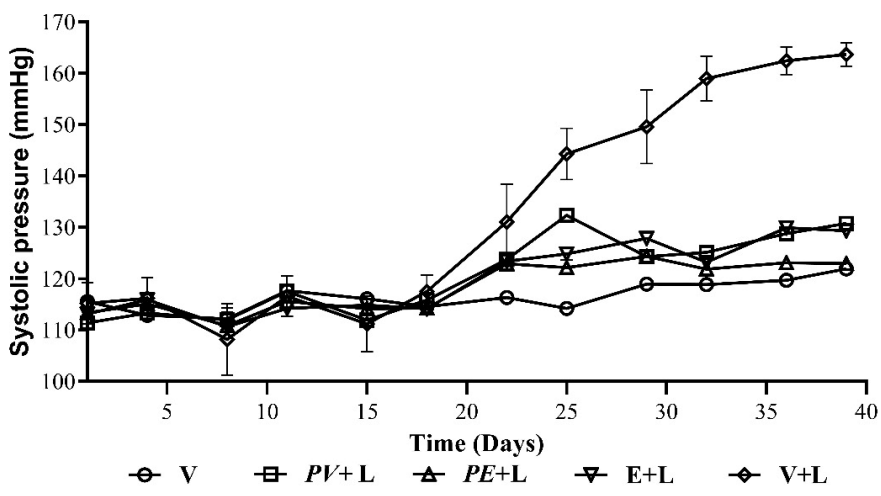

Figure 2. Antihypertensive potential of the extracts, PAS of hypertensive rats induced by L-NAME. Each point represents the mean of the SP \pm SEM.

contrasts with the SBP of hypertensive animals which increased significantly $(p<0.0001)$ compared to animals treated with the extracts, enalapril, and vehicles. This favorable effect of the extracts could be attributed to different metabolites groups identified in the extracts (Table 2), since phenolic compounds (found in high concentration) and Passiflora alkaloids have been reported to generate a protective and hypotensive effect in both in vivo and in vitro models (Carrón et al., 2010; Wang et al., 2014); it is possible that it should be noted that the rats with the lowest increase in SBP were those treated with the extract of $P$. edulis, which evidenced a higher content of the quantified polyphenols.

Table 2. Phytochemical screening.

\begin{tabular}{|c|c|c|c|}
\hline Metabolite & Test & $\begin{array}{c}\text { Ethanolic extract } \\
\text { P. edulis }\end{array}$ & $\begin{array}{c}\text { Ethanolic extract } \\
\text { P. vitifolia }\end{array}$ \\
\hline Polyphenols & Folin-Ciocalteu & +++ & +++ \\
\hline \multirow{2}{*}{ Flavonoids } & Shinoda & +++ & +++ \\
\hline & TLC & +++ & +++ \\
\hline Tannins & Ferric chloride & +++ & +++ \\
\hline \multirow{2}{*}{ Saponins } & Rosenthaler & N.D. & N.D. \\
\hline & Foam & N.D. & N.D. \\
\hline Anthraquinones & Borntrager & + & + \\
\hline \multirow{3}{*}{ Terpenes and steroids } & Lieberman-Burchard & +++ & +++ \\
\hline & Salkowski & +++ & +++ \\
\hline & TLC & +++ & +++ \\
\hline \multirow{4}{*}{ Alkaloids } & Tanred & ++ & ++ \\
\hline & Dragendorff & ++ & ++ \\
\hline & Mayer & ++ & ++ \\
\hline & Valser & N.D. & N.D. \\
\hline Cardiotonics & Baljet & + & + \\
\hline Total phenols (g E.A.G/100 g extract) & Folin-Ciocalteu & $43.2 \pm 1.0$ & $33.07 \pm 0.68$ \\
\hline Flavonoids ( $\mathrm{g}$ E.N/100 g extract) & Aluminum trichloride & $15.24 \pm 0.73$ & $13.64 \pm 0.97$ \\
\hline Total tannins (g E.A.T/100 g extract) & Folin-Ciocalteu Polyvinyl pyrrolidone & $15.08 \pm 0.47$ & $10.77 \pm 0.42$ \\
\hline
\end{tabular}

N.D. indicates no detection of secondary nucleus under these conditions, + indicates low quantity, ++ indicates medium quantity, and +++ indicates high quantity. g E.A.G = equivalent grams of gallic acid; g E.N = equivalent grams of naringenin; g E.A.T = equivalent grams of tannic acid.

Adapted from (Murillo \& Méndez, 2012). 


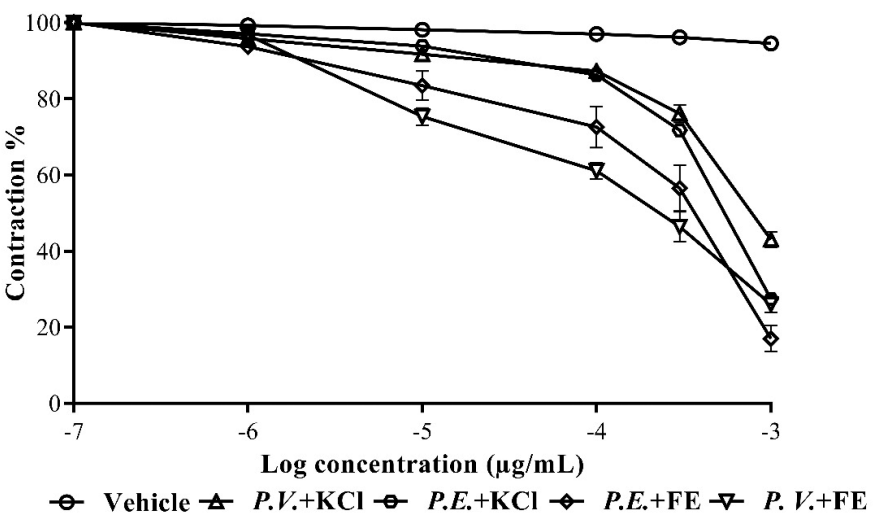

Figure 3. Relaxation exerted by the extracts in aortic rings contracted with $\mathrm{FE}$ and $\mathrm{KCl}$. Each point represents the mean $\pm \mathrm{SEM}$.

Relaxing effect of the extracts on the contraction exerted by phenylephrine (Phe) and $\mathrm{KCl}$

The extracts showed relaxation in aortic rings contracted with Phe and $\mathrm{KCl}$ (Fig. 3), being greater in the rings treated with the extract of $P$. edulis. It was possible to show greater activity on the part of the two extracts in the rings contracted with Phe, finding significant differences in the maximum response between the treatments and the compounds used to contract the rings. The relaxation induced by the extracts of the two species presented concentration response behavior, suggesting that the effects may be linked to intracellular calcium movement stimulated by different mechanisms that act on voltage-dependent $\mathrm{Ca}^{+2}$ channels (Clark et al., 2001; Costa, 2013; Wang et al., 2014).

Effect of ACh and NPS on aortic rings of hypertensive rats treated with the extracts

Chronic exposure to L-NAME generates a decreased vascular response (Bryant et al., 1995). In this work, it was not possible to maintain the vascular response of the animals by cumulative action of ACh and NPS (Figs. 4 and 5), since a decrease is observed with respect to that obtained in normotensive rats. It is evidenced that the aortic rings obtained from animals treated with the extracts showed greater relaxation than those treated with

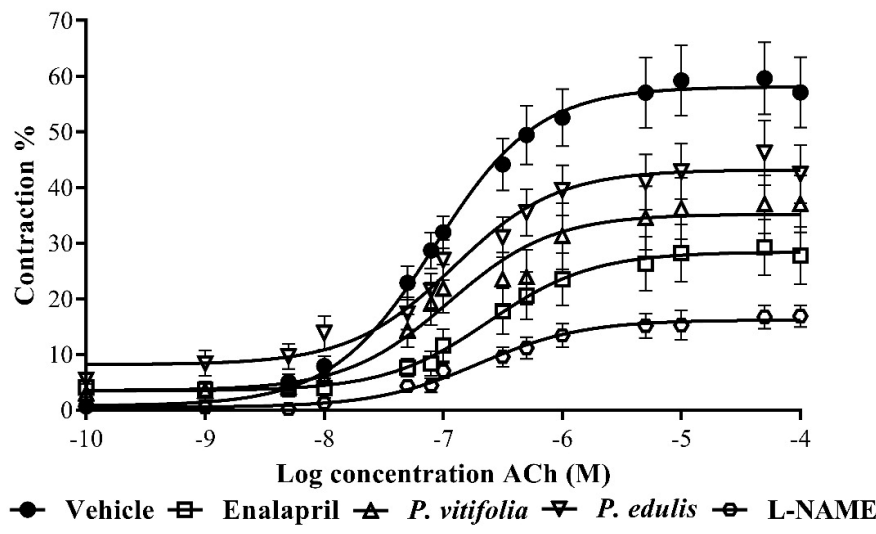

Figure 4. Relaxation by ACh $\left(10^{-10}-10^{-4} \mathrm{M}\right)$ in aortic rings of hypertensive Wistar rats treated with the extracts of the two species, enalapril, and vehicle (control). Results are expressed as means \pm SEM.

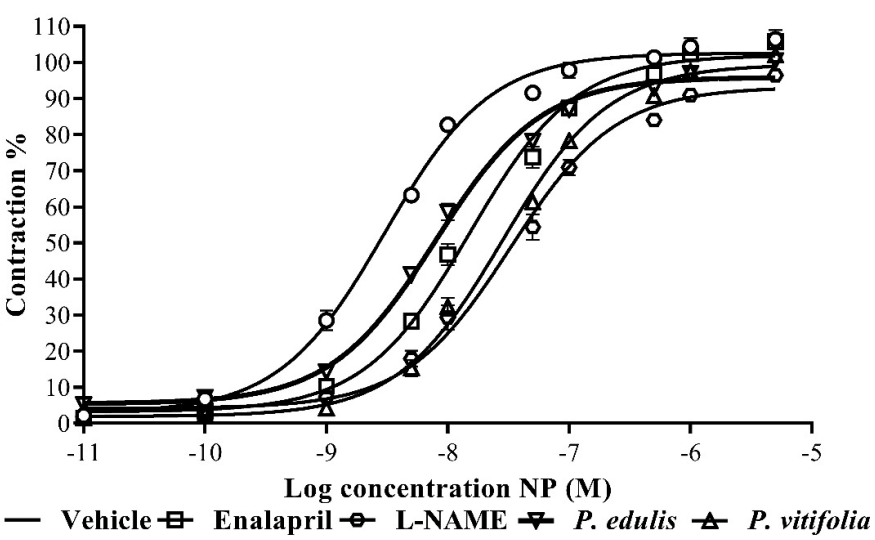

Figure 5. Relaxation by NPS $\left(10^{-11}-10^{-5} \mathrm{M}\right)$ in aortic rings of hypertensive Wistar rats treated with the extracts of the two species, enalapril, and vehicle. Results are expressed as means \pm SEM.

enalapril and hypertensive rats. In both cases, a shift to the right of the curve was observed with respect to the control, which could indicate a decrease in the potency and/or antagonistic action by the extracts to the relaxing action of the two compounds on the aortic rings (Aleixandre and Ortega, 2000).

\section{Extract mechanism of action}

\section{Relaxation in the presence of L-NAME}

The relaxing action of the two ethanolic extracts on aortic rings precontracted with Phe and incubated with the agents mentioned above did not show significant differences, except for L-NAME, which partially reversed the relaxation compared to rings without the presence of it (Fig. 6). The evaluation of the synthesis of nitric oxide by adding L-NAME to the organ bath showed that this partially reduces the relaxing capacity of the two extracts compared to that produced in its absence, which suggests that the relaxing effect of the extract could be dependent on the endothelium and would be directly related to the synthesis of nitric oxide (Pérez et al., 2010; Wang et al., 2014).

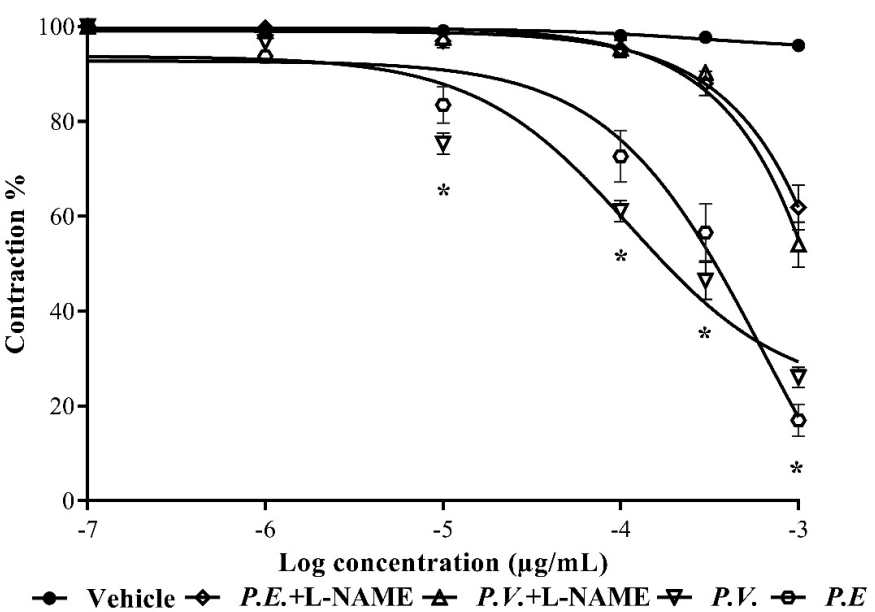

Figure 6. Relaxation of the extracts in the presence and absence of L-NAME. Each point represents the mean $\pm \mathrm{SEM}$; *represents differences $(p \leq 0.05)$ between treatments in the presence and absence of L-NAME. 


\section{Inhibitory effect of the extracts on the contraction exerted by} AT-II

Ethanolic extracts of two species inhibited contraction produced by AT-II in aortic rings. It was observed that the extract of $P$. edulis at the two concentrations evaluated presented a greater inhibitory effect than the extract of $P$. vitifolia (Fig. 7). Contraction of the rings by cumulative doses of AT-II in rings preincubated with extracts showed a concentration-dependent effect, being the $P$. edulis extract the one that showed the greatest inhibition of AT-II. When comparing the effect of the extracts with that of Losartan (AT-II inhibitor), higher effectiveness was obtained than that caused by the reference drug, which is a selective inhibitor of the AT1 receptor which reduces the effects of AT-II in the artery

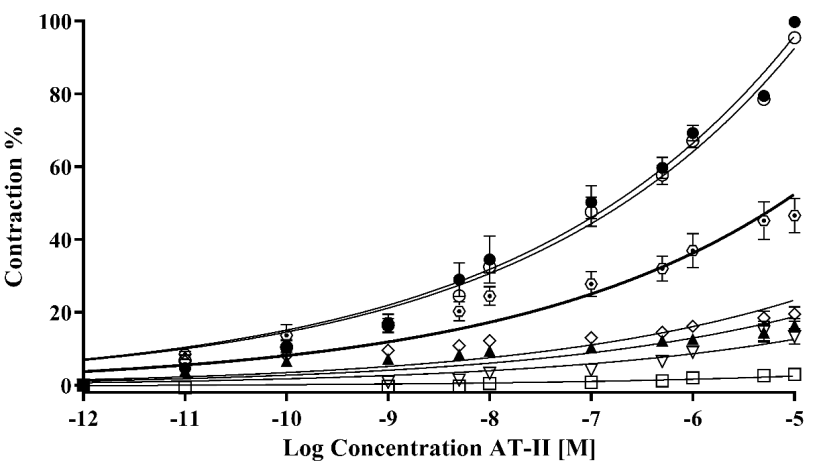

$\bullet$ AT-II $๑$ AT-II+V $\rightarrow$ AT-II $+\mathrm{L}[10 \mu \mathrm{mol} / \mathrm{mL}] \bullet$ AT-II $+P E[300 \mu \mathrm{g} / \mathrm{mL}]$ $\rightarrow$ AT-II $+P E[300 \mu \mathrm{g} / \mathrm{mL}] \rightarrow A T-I+P V[30 \mu \mathrm{g} / \mathrm{mL}]-\triangle A T-I I+P E[30 \mu \mathrm{g} / \mathrm{mL}]$

Figure 7. Comparison between contraction exerted by AT-II on aortic rings in the presence and absence of the extracts, Losartan, and vehicle. Each point represents the mean \pm SEM.
(Pérez et al., 2010). The two extracts could act as possible AT-II inhibitors; however, a greater effect $(p \leq 0.05)$ of the extract of $P$. edulis than that produced by $P$. vitifolia is observed; the above could be related to the concentration of phenolic compounds greater in the extract of $P$. edulis (Table 2).

\section{UHPLC-DAD analysis}

The results of the characterization of the two extracts by UHPLC-UV can be seen in Table 3 and Figure 8 . Chromatographic analysis showed the presence and quantification of vitexin, orientin, isovitexin, isoorientin, coumaric acid, rutin, and quercetin, using curves made with the reference compounds. Other chromatographic signals were evidenced that showed characteristic UV spectra of polyphenols but that could not be identified or quantified because they did not correspond to the standards used. Similarly, quantitation of phenolic compounds (total phenols, total flavonoids, and tannins) revealed the high content of these in the two extracts (Table 2). It should be noted that some c-glycosides flavonoids such as orientin and vitexin are used in Passiflora as chemomarkers of the genus; however, these reports refer to extracts obtained from stem and leaves but not from seeds (Gomes et al., 2017; Petenatti et al., 2014; Sepúlveda et al., 2018; Wosch et al., 2017; Zeraik and Yariwake, 2010). On the other hand, some authors (Bayard et al., 2007; Occhiuto and Limardi, 1994; Occhiuto et al., 1990) indicated the positive effect of said compounds on the vascular behavior of animals with HTA and the protective potential they present on target tissues related to pathology (Orhan et al., 2003); however, it is necessary to carry out tests that allow the different compounds present in the extracts of the two Passiflora to be correlated with the different pharmacological targets related to HTA.

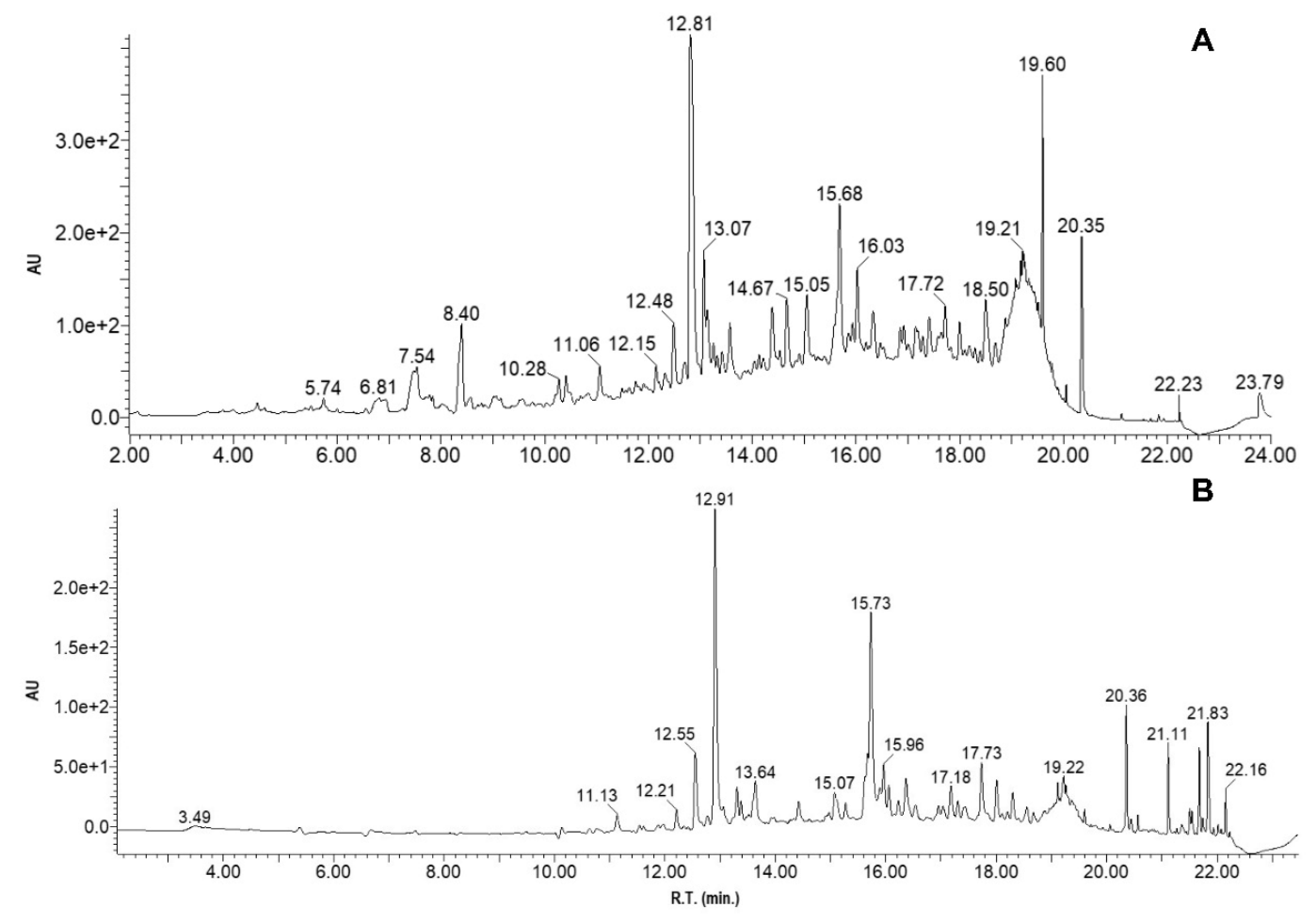

Figure 8. (A) Chromatograms of extracts from P. vitifolia and (B) P. edulis f. edulis, with diode array detection at $340 \mathrm{~nm}$. 
Table 3. Phenolic compounds in $P$. edulis and $P$. vitifolia seeds determined by UHPLC-UV.

\begin{tabular}{cccc}
\hline Compound & R.T. (minutes) & P. edulis f. edulis & Concentration $\boldsymbol{\mu g} / \mathbf{g}$ \\
\hline Isoorientin & 2.55 & 51.79 & $\boldsymbol{P}$. vitifolia \\
Isovitexin & 3.59 & 421.56 & 133.3 \\
Orientin & 4.15 & 34.80 & 368.43 \\
Vitexin & 5.46 & 341.59 & 302.37 \\
Coumaric acid & 10.51 & 54.0 & 88.82 \\
Rutin & 12.22 & N.D. & 78.4 \\
Quercetin & 13.84 & 99.6 & 48.8 \\
\hline
\end{tabular}

N.D. indicates the nondetection of the compound evaluated under the applied conditions.

\section{CONCLUSION}

This study demonstrates that the two ethanolic extracts obtained from the seeds of $P$. edulis f. edulis and $P$. vitifolia prevented HTA induced by nitric oxide deficit in rats; however, P. edulis f. edulis had a greater effect, obtaining SBP similar to those of normotensive animals. The possible mechanisms of action for the extracts are primarily related to the synthesis of nitric oxide and inhibition of AT-II; these results, together with the not apparent toxicity in cell, no acute toxicity in mice and the chemical composition, that relates the activity with the presence of phenolic compounds be in agreement to studies previously carried out on seeds of the genus; the above, postulates the two species as a possible source of extracts with antihypertensive potential, reinforcing the ethnobotanical use of the genus Passiflora for the control of hypertension. In addition, this type of results contributes to the generation of added value to the agroindustrial waste of these two species through its use in obtaining extracts with biological potential.

\section{ACKNOWLEDGMENTS}

The authors acknowledge the National University of Colombia, Tolima University, the research's office of the University of Tolima, the Bioterium of the Pharmacy Department, the Molecular Pharmacology Laboratory (FARMOL), and the Research Group on Natural Products of the University of Tolima (GIPRONUT).

\section{AUTHOR CONTRIBUTIONS}

All authors made substantial contributions to conception and design, acquisition of data, or analysis and interpretation of data; took part in drafting the article or revising it critically for important intellectual content; agreed to submit to the current journal; gave final approval of the version to be published; and agree to be accountable for all aspects of the work. All the authors are eligible to be an author as per the international committee of medical journal editors (ICMJE) requirements/guidelines.

\section{CONFLICT OF INTEREST}

The authors declare no conflict of interest in carrying out this work.

\section{FUNDING}

None.

\section{ETHICAL APPROVALS}

The Bioethics Committee of the Faculty of Sciences, National University of Colombia, Bogotá headquarters, endorsed the implementation of the project under Act 16 of September 13, 2016.

\section{PUBLISHER'S NOTE}

This journal remains neutral with regard to jurisdictional claims in published institutional affiliation.

\section{REFERENCES}

Aguillón J, Maldonado M, Loango N, Arango S, Landázuri P. Actividad antioxidante y antiproliferativa de extractos etanólicos y acuoso de las hojas y el jugo del fruto de Passiflora edulis. Perspect Nutr Hum, 2013; 15(1):13

Aleixandre M, Ortega A. Función y disfunción endotelial. Editorial Complutense, Madrid, España, 2000.

Alves JS, Marques JI, Demarque DP, Costa LR, Amaral JG, Lopes NP, da Silva-Júnior AA, Soares LAL, Gavioli, EC, Ferreira LS, Zucolotto SM. Involvement of isoorientin in the antidepressant bioactivity of a flavonoid-rich extract from Passiflora edulis f. flavicarpa leaves. Rev Bras Farmacogn, 2020; 30:1-11.

Alvarez-Rivera G, Ballesteros-Vivas D, Parada-Alfonso F, Ibañez E, Cifuentes A. Recent applications of high resolution mass spectrometry for the characterization of plant natural products. TrAC Trends Anal Chem, 2019; 112: 87-101.

Ballesteros-Vivas D, Alvarez-Rivera G, Ibánez E, ParadaAlfonso F, Cifuentes A. Integrated strategy for the extraction and profiling of bioactive metabolites from Passiflora mollissima seeds combining pressurized-liquid extraction and gas/liquid chromatography-high resolution mass spectrometry. J Chromatogr A, 2019; 1595:144-57.

Bareño L. Estudio de la actividad antihipertensiva de Passiflora quadrangularis $\mathrm{L}$ en ratas con hipertensión inducida por déficit de óxido nítrico. (Tesis de maestría) Universidad Nacional de Colombia. Bogotá, Colombia, 2015.

Bareño LL, Puebla P, Guerra CM, San Feliciano A, Isaza G, Guerrero MF. Passiflora quadrangularis L. prevents experimental hypertension and vascular remodelling in rats exposed to nitric oxide deficit. Vitae, 2017; 24(3):186-95.

Bayard V, Chamorro F, Motta J, Hollenberg NK. Does flavanol intake influence mortality from nitric oxide-dependent processes? Ischemic heart disease, stroke, diabetes mellitus, and cancer in Panama. Int J Med Sci, 2007; 4:53-8.

Brown MT, Bussell JK. Medication adherence: WHO cares? Mayo Clin Proc, 2011; 86(4):304-14.

Brunton L, Lazo J, Parker K. (Ed.). Goodman and Gilman's the pharmacological basis of therapeutics. 11th edition, McGraw Hill, New York, NY, pp 789-800, 2006. 
Bryant CE, Allcock GH, Warner TD. Comparison of effects of chronic and acute administration of NG-nitro-L-arginine methyl ester to the rat on inhibition of nitric oxide-mediated responses. Br J Pharmacol, 1995; 114(8):1673-9.

Cárdenas P, Aragón D, Ospina L, Isaza G, Pérez J. Efecto de algunas especies vegetales antiinflamatorias sobre la actividad enzimática de elastasa y mieloperoxidasa. Rev Colomb Cienc Quim Farm, 2012; 41(2):157-48.

Carrón R, Sanz E, Puebla P, Martín M, San Roman L, Guerrero M. Mechanisms of relaxation induced by Flavonoid ayanin in isolated aorta rings from Wistar rats. Rev Colomb Med, 2010; 41:10-6.

Clark M, Finkel R, Rey J, Whalen K. Farmacología. 5ta Edición, Lippincott Williams andWilkins. Philadelfia, PA, 2001.

Commission of the European Communities. Annex to Commission Directive 92/69/EEC of 31 July 1992 adapting to technical progress for the seventeenth time Council Directive 67/548/EEC on the approximation of laws, regulations and administrative provisions relating to the classification, packaging and labelling of dangerous substances. B.1 Acute toxicity (oral) Off J Eur Comm, 1992; 35:110-2.

Contreras J, Calderón L, Guerra E, García B. Antioxidant capacity, phenolic content and vitamin $\mathrm{C}$ in pulp, peel and seed from 24 exotic fruits from Colombia. Food Res Int, 2011; 44(7):2047-53.

Costa G. Estudo químico de espécies brasileiras e colombianas do gênero Passiflora. Memoria para optar al título de Doctor en Farmacia, Facultad de Farmacia, Universidade Federal de Santa Catarina, Florianópolis, Brazil, 2013.

Cupitra N, Calderón J, Narvaez R. Influence of ageing on vascular reactivity and receptor expression in rabbit aorta: a complement to elastocalcinosis and smooth muscle mechanisms. Clin Interv Aging, 2020; 15:537-45.

Delpino-Rius A, Eras J, Vilaró F, Cubero MÁ, Balcells M, CanelaGarayoa R. Characterisation of phenolic compounds in processed fibres from the juice industry. Food Chem, 2015; 172:575-84.Dhawan K, Dhawan S, Sharma A. Passiflora: as review update. Ethnopharmacol, 2004; 94:1-23.

Dominguez X. Métodos de investigación fitoquímica. Limusa, Mexico City, Mexico, 1973

Gomes SV, Portugal LA, dos Anjos JP, de Jesus ON, de Oliveira EJ, David JP, David JM. Accelerated solvent extraction of phenolic compounds exploiting a Box-Behnken design and quantification of five flavonoids by HPLC-DAD in Passiflora species. Microchem J, 2017; 132:28-35.

Ingale SP, Kasture SB. Antioxidant and antiparkinsonian activity of Passiflora incarnata leaves. Orient Pharm Exp Med, 2014; 14(3):231-6.

Jiménez A, Rodríguez L, Murillo W, Méndez J, Rueda E. Antifeedant activity of secondary metabolites of citrus waste on Spodoptera frugiperda (Lepidoptera: Noctuidae). Rev Colomb Entomol, 2013; 39(1):113.

Karapetsas A, Voulgaridou GP, Konialis M, Tsochantaridis I, Kynigopoulos S, Lambropoulou M, Stavropoulou MI, Stathopoulou K, Aligiannis N, Bozidis P, Goussia A, Gardikis K, Panayiotidis MI, Pappa A. Propolis extracts inhibit UV-induced photodamage in human experimental in vitro skin models. Antioxidants, 2019; 8(5):125.

Lorenzo P, Moreno A, Leza J, Lizasoain I, Moro M, Portolés A. Farmacología Básica Clínica. 18th edición, Editorial Médica Panamericana, Madrid, Spain, pp 73-8, 2008.

Mantovani MDF, Hereibi MJ, Arthur JP, Mattei ÂT, Madureira $\mathrm{AB}$, Ferraz MIR. Complementary and alternative medicine in systemic arterial hypertension. Br J Card Nurs, 2017; 12(4):180-6.

Mosmann, T. Rapid colorimetric assay for cellular growth and survival: 72 application to proliferation and cytotoxicity assays. J Immunol Methods, 1983; 65:55-63.

Murillo E, Méndez J. Guía rápida para la determinación de núcleos secundarios en extractos vegetales. Universidad del Tolima, Tolima, Colombia, 2012

Ocampo J, Coppens G, Jarvis A. Distribution of the genus Passiflora L. diversity in Colombia and its potential as an indicator for biodiversity management in the Coffee Growing Zone. Diversity, 2010; 11:1158-80.

Occhiuto F, Limardi F. Comparative effects of the flavonoids luteolin, apiin and rhoifolin on experimental pulmonary hypertension in the dog. Phytother Res, 1994; 8:153-6.Occhiuto F, Pasquale A, Briguglio F. Comparative haemodynamic effects of the flavonoids rhoifolin and vitexin in the dog. Phytother Res, 1990; 4:118-20.

Orhan DD, Aslan M, Aktay G, Ergun E, Yesilada E, Ergun F. Evaluation of hepatoprotective effect of Gentiana olivieri herbs on subacute administration and isolation of active principle. Life Sci, 2003; $72: 2273-83$.

Pérez T, López R, López P, Castillo C, Castillo E. Lack of heterologous receptor desensitization induced by angiotensin II type 1 receptor activation in isolated normal rat thoracic aorta. Vasc Pharmacol 2010; 54:29-35.

Petenatti ME, Gettel MA, Popovich MC, Garro MF, Camí G, Aragón, L., Del Vitto LA, Petenatti EM. Identificación de C-glicosilflavonas por HPLC y FTIR en extractos acuosos y metanólicos de Passiflora caerulea y P. foetida (Passifloraceae). Dominguezia, 2014; 30(1):35-42.

Piepoli MF, Hoes AW, Agewall S, Albus C, Brotons C, Catapano AL, Cooney MT, Corrà U, Cosyns B, Deaton C, Graham I, Hall MS, Hobbs FDR, Løchen ML, Löllgen H, Marques-Vidal P, Perk J, Prescott E, Redon J, Richter DJ, Sattar N, Smulders Y, Tiberi M, van der Worp HB, van Dis I, Verschuren WMM, Binno S, ESC Scientific Document Group. 2016 European guidelines on cardiovascular disease prevention in clinical practice: the sixth joint task force of the European society of cardiology and other societies on cardiovascular disease prevention in clinical practice (constituted by representatives of 10 societies and by invited experts) developed with the special contribution of the European Association for Cardiovascular Prevention and Rehabilitation (EACPR). Eur Heart J, 2016; 37(29):2315-81.

Pinzón I, Fischer G, Corredor G. Determinación de los estados de madurez del fruto de la gulupa (Passiflora edulis Sims.). Agron Colomb, 2007; 25(1):83-95.

Podolak I, Galanty A, Sobolewska D. Saponins as cytotoxic agents: a review. Phytochemistry Rev, 2010; 9(3):425-74.

Rodríguez M, Vergel N, Ospina L, Calle J, Pinzón R. Evaluación de actividades enzimáticas elastasa y mieloperoxidasa como marcadores de degranulación leucocitaria en modelos de inflamación aguda. Rev Col Cienc Quím Farm, 2004; 34(1):35-45.

Rojas J. Estudio preclínico y clínico de la seguridad y actividad antihipertensiva de Passiflora edulis Sims (maracuyá). Memoria para optar al título de Doctor en Farmacia y Bioquímica, Facultad de Farmacia y Bioquímica, Universidad Nacional Mayor de San Marcos, Lima, Perú, 2009.

Rudnicki M, Oliveira MR, da Veiga Pereira T, Reginatto FH, Dal-Pizzol F, Moreira JCF. Antioxidant and antiglycation properties of Passiflora alata and Passiflora edulis extracts. Food Chem, 2007; 100: 719-24.

Saleem U, Amin S, Ahmad B, Azeem H, Anwar F, Mary S. Acute oral toxicity evaluation of aqueous ethanolic extract of Saccharum munja Roxb. roots in albino mice as per OECD 425 TG. Toxicol Rep, 2017; $4: 580-5$.

Schlede E, Genschow E, Spielmann H, Stropp G, Kayser D Oral acute toxic class method: a successful alternative to the oral LD50 test. Regul Toxicol Pharmacol, 2005; 42(1):15-23.

Sepúlveda P, Costa GM, Aragón DM, Ramos F, Castellanos L. Analysis of vitexin in aqueous extracts and commercial products of Andean Passiflora species by UHPLC-DAD. J Appl Pharm Sci 2018; 8(09):081-6.

Shouk R, Abdou A, Shetty K, Sarkar D, Eid AH. Mechanisms underlying the antihypertensive effects of garlic bioactives. Nutr Res, 2014; 34(2):106-15

Silva Filho DFD, Batista MRA, Aguiar JPL, Machado FM, Figueiredo JNR, Ticona-Benavente CA. Passiflora foetida yielding and nutritional composition. Rev Brasileira Fruticultura, 2019; 41(3). 
Tedla YG, Bautista LE. Drug side effect symptoms and adherence to antihypertensive medication. Am J Hypertens, 2016; 29(6):772-9.

Torres M, Ibáñez P, y Pabón, M. Vasodilatación inducida por Croton schiedeanus Schlecht vinculada con la ruta metabólica de guanilato ciclasa. Rev Col Cienc Quím Farm, 2012; 41(1):36.

Vanvliet N, Chafe L, Vladan A, Schnyder-Candrian S, Montani JP. Direct and indirect methods used to study arterial blood pressure. J Pharmacol Toxicol Methods, 2000; 44:361-73.

Viganó J, de Paula Assis BF, Náthia-Neves G, dos Santos P, Meireles MAA, Veggi PC, Martínez J. Extraction of bioactive compounds from defatted passion fruit bagasse (Passiflora edulis sp.) applying pressurized liquids assisted by ultrasound. Ultrason Sonochem, 2020; 64:104999.

Wang H, Lu J, Zhang G, Li X, Peng H, Lu Y, Zhao L, Ye Z, Bruce I, Xia Q, Qian L. Endothelium- dependent and independent vasorelaxant actions and mechanisms induced by total flavonoids of Elsholtzia splendens in rats aortas. Environ Toxicol Pharmacol, 2014; 38:453-9.

World Health Organization. Prevention of chronic diseases: a vital investment. Recuperado el 7 de febrero de 2020 de la Word Wide Web. Available via http://www.who.int/chp/chronic disease report/overview sp.pdf
Wosch L, Imig DC, Cervi AC, Moura BB, Budel JM, de Moraes Santos C A. Comparative study of Passiflora taxa leaves: I. A morphoanatomic profile. Rev Brasileira Farmacogn 2015; 25(4):328-43.

Wosch L, Santos KCD, Imig DC, Santos CAM. Comparative study of Passiflora taxa leaves: II. A chromatographic profile. Rev Bras Farmacognosia, 2017; 27(1):40-9.

Zeraik ML, Yariwake JH. Quantification of isoorientin and total flavonoids in Passiflora edulis fruit pulp by HPLC-UV/DAD. Microchem J, 2010; 96(1):86-91.

How to cite this article:

Jiménez ÁAR, Méndez JJA, Murillo WA, Guerrero MFP. Vasodilator effect of ethanolic extracts of Passiflora vitifolia and Passiflora edulis f. edulis seeds. J Appl Pharm Sci, 2021; 11(10):061-069. 